\title{
New frontiers in chemical energy and environmental engineering
}

\author{
Srinath Suranani ${ }^{1}$ (D) $\cdot$ Sandeep Kumar $^{2} \cdot$ Sundergopal Sridhar $^{3}$
}

Received: 22 August 2016/Accepted: 31 August 2016

(C) Springer-Verlag Berlin Heidelberg 2016

Energy is one of the major building blocks of modern society. Industries are attributed to be the main source of environmental pollution. The problems associated with the energy and environment have now become the subject of international debate. Engineers play vital role in devising environmental pollution mitigating techniques and developing sustainable energy technologies.

In the context above, the department of Chemical Engineering, National Institute of Technology Warangal, India, on the occasion of its Golden Jubilee organized an International Conference on New Frontiers in Chemical Energy and Environmental Engineering (INCEEE) during March 20-21, 2015.

The conference theme has potential significance to the diverse disciplines of chemical, biotechnological, and energy sectors that contribute significantly to nation development. In addition to the main themes, the conference has also covered the recent important areas in chemical and allied fields such as CFD, Green technology, process intensification and novel separation techniques, and process systems engineering application.

Responsible editor: Philippe Garrigues

Srinath Suranani

srinath@nitw.ac.in

1 Department of Chemical Engineering, NIT Warangal, Warangal, India

2 Department of Civil \& Environmental Engineering, Old Dominion University, Norfolk, VA, USA

3 Chemical Engineering Division, IICT Hyderabad, Hyderabad, India
The objective of the conference was to provide a technical get-together for the academicians, personnel from the research laboratories and industry for reciprocating the advances/recent findings in the areas of chemical, energy, and environmental engineering.

The conference received an overwhelming response from several researchers across the globe contributing around 280 original research articles covering all themes of the conference. The submitted papers were properly reviewed by independent members of the academic staff and selected 170 papers for oral presentation and 12 papers for poster presentation. According to the rules adopted for the conference organization, all the papers were presented by authors within thematic sessions. Two keynote sessions were also held on clean energy and environmental management by eminent speakers from USA and India. Selected scientific papers, after proper revision and another round of review by the scientific committee, were published in this special issues of Environmental Science and Pollution Research (Springer) and Chemical Process and Product modeling (De grutyr).

The collection included in this special issue covers topics related to the efficient removal of phenolic compounds by catalytic wet oxidation and phtocatalytic degradation using $\mathrm{Ag} @ \mathrm{TiO} 2$ nanoparticles, treatment of high strength nitrogenous waste water and sludge characterization, synthesis of $\mathrm{Fe}$ doped nano catalyst for dye removal from textile water, removal of 2,4-Dichlorophenoxyacetic acid, experimental studies for the production of biodiesel from waste oil, thermodynamic analysis of chemical looping combustion, and peclet number analysis of PEM fuel cells. All these papers will stimulate new ideas, methods, and applications in ongoing advances in this growing area of chemical, environmental, and energy engineering. 


\section{Conclusions}

This special issue, dedicated to INCEE, provided an overview of diversity of topics related to environmental and energy engineering. The Guest editors believe that the selected papers will considerably extend the knowledge of body published in Environment Science \& Pollution Research journal and will be of interest to its readers.

Acknowledgments As guest editors, we would like to express our appreciation to all the presenters and authors of the conference. The Guest editors would like to thank all the reviewers who have made most valuable and highly appreciated contributions by reviewing, commenting and advising the authors. Special thanks should go to the administrative staff of the ESPR journal for their excellent support.

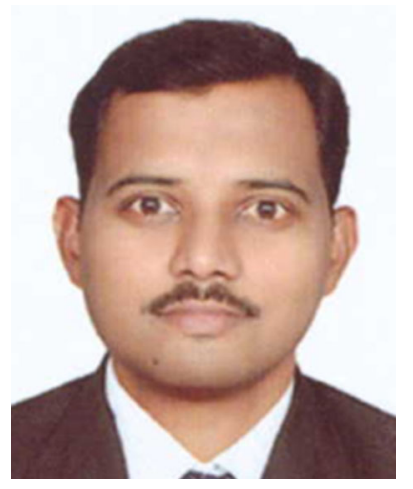

Dr. Srinath Suranani is currently an Associate Professor in the Department of Chemical Engineering in the National Institute of Technology Warangal. He obtained his Ph.D. in Chemical Engineering from National Institute of Technology Warangal, India. His main areas of scientific research are Thermal conversion of solid waste, bio fuels, catalysis, micro reactors and Process modeling and Simulation. He has completed three MHRD sponsored R\&D projects and presently executing R\&D projects sponsored by ISRO \& DRDO. Besides R\&D projects, he has also involved in consultancy projects on simulation of process plants and also filed two Indian patents. He has published over 25 research articles in National, International Conference Proceedings and journals. He has organized an International conference on New Frontiers in Chemical, Energy and Environmental Engineering during March 2015.

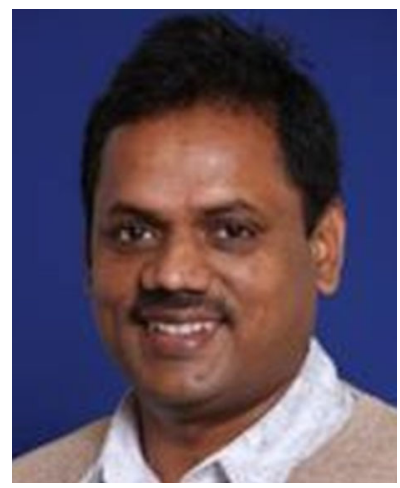

Dr. Sandeep Kumar earned a doctoral degree in Chemical Engineering and has been an Assistant Professor and Director, Energy Cluster in the Department of Civil \& Environmental Engineering at Old Dominion University, Norfolk, Virginia. His areas of interest are supercritical fluids (CO2 and water), biofuels, and the applications of chemical and environmental engineering concepts to produce renewable fuels. He has been a regular reviewer for several scientific international journals and have served on numerous NSF proposals grant panels for Small Business Innovation Research and Small Business Technology Transfer Programs. He has set up a biofuel laboratory consisting of advanced instruments and have been able to generate more than $\$ 750,000$ of sponsored research including the prestigious NSF CAREER award. Besides the current academic career, he has more than 12 years of experience in industry and R\&D including 10 years as Scientific Officer (C, D, \& E) at Bhabha Atomic Research Center, Trombay, Mumbai, India, with responsibilities in new process development, process engineering, and project management. Full current $\mathrm{CV}$ with publication lists can be found at http://www.odu.edu/directory/people/s/skumar, http://www.odu. edu/eng/research/clusters/energy.

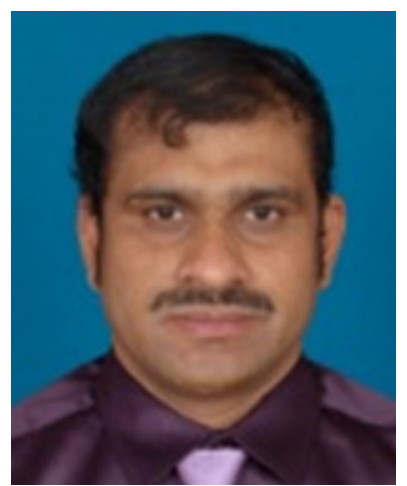

Dr. Sundergopal Sridhar is a Chemical Engineer from the University College of Technology, Osmania University, Hyderabad, who has been working as a Scientist in the area of Membrane Separation Processes at the CSIR-IICT, Hyderabad, for the past 17 years during which he has developed several technologies for chemical industries besides contributing immensely to rural welfare through water purification projects and academic development via extensive HRD and laboratory development in several schools and colleges. Major highlights of his career include (i) commissioning of several membrane pilot plants of varying capacities based on Electrodialysis, Nanofiltration, and Gas Permeation to facilitate solvent recovery, effluent treatment, and gas purification in pharmaceutical, textile, and petrochemical industries and (ii) design and installation of 12 model defluoridation plants of 600 $4000 \mathrm{~L} / \mathrm{h}$ capacity and 15 highly compact low cost systems of 100 $200 \mathrm{~L} / \mathrm{h}$ capacity for purification of ground water for more than 1 lakh population in fluorosis-affected villages of Telangana, Andhra Pradesh, and Tamil Nadu, India. A cascaded automated membrane system for production of zero TDS water for medical purposes, bioprocess, batteries, and caustic soda plants is one of his other inventions. Dr. Sridhar has published 117 research papers with a h-index of 32. He has seven foreign patents to his credit. 